\title{
Environment Condition of Indonesian Migrant Worker in The Destination Countries And The Amount of Remittance Delivery to Origin Region
}

\author{
Budijanto \\ State University of Malang \\ Corresponding email: budijanto.fis@um.ac.id \\ Wan Ibrahim Wan Ahmad \\ Department of Geography, \\ School of Social Development, College of Arts and Sciences, \\ Universiti Utara Malaysia
}

\begin{abstract}
The research area about two decades ago is an area that most of the poor people were working in agriculture, the cultivation of dry land, with an area of arable land holdings averaging less than 0.2 ha. Their remittances, in just one decade the area has been turned into an area at the center of economic activity diverse community, neighborhood conditions are arranged, and luxurious impression, the growing flow of transport and communications make the economic wheels have spun it appears in the bustle of economic activity community. Hence the importance of exposing working conditions migrant workers in destination countries that affect the delivery of remittances from destination countries to their home area. Therefore, the aim of this research is to discover and reveal the influences of the determinants behind lartar working environment TKI environmental conditions in destination countries against the remittance delivery to their home area. The research approach used is a quantitative approach. It also uses survey methods, data collection by interview. The research location is Tulungagung. The results showed that determinant background working environment in the destination country of TKI provide great influences on the remittance delivery to their home area. The results of the study include 1) Region destination country labor migrants working in the Far East of remittances sent to the place of origin is greater than the migrant workers working in the Middle East and Southeast Asia,, 2) The status of migrant workers who of legality of remittances sent to the region origin is greater than the illegal status, 3) Long working migrant workers in the destination country the larger the number of years, remittances sent to their home area larger than workers who work shorter.
\end{abstract}

Keywords-International Migration, Environment, Destination Countries, Remittances, Region of Origin

\section{INTRODUCTION}

There is an increasing rate of workers to go abroad, especially in developing countries such as Indonesia, this is determined by the supporting factors in the home areas, especially the economic difficulty factor and attractive factor, which is a high salary in destination area compared to the salary in the home areas. There is a great variation on the number of Indonesian workers to go abroad in each of the destination countries, but recent data show that Malaysia is still the main destination country for Indonesian migrant workers, and there is more number of illegal Indonesian migrant workers in Malaysia. Thus it is not a mistake for those who perform international migration is to improve the economic life of families with income earned in the region where he desires (Salladien, 1999). This was confirmed by (Setiadi, 2004) that there is a relationship between international migration with socio-economic changes.

The form of economic aspect of foreign migrant workers is in the form of money or goods (remittances) to their home area. In general with the presence of remittances, it is expected that through the utilization can achieve changes in the socioeconomic improvement of households (Goma, 1993). The amount of remittances to the region of origin vary widely, and depending on the circulation (Goma, 1993). Remittances sent overseas migrant workers to their families in the area of origin is the primary source of revenue. The delivery can be through services of banks, post or any friends who return to the villages. In general, through their remittances, it is expected that through its utilization, it can be achieved any changes in social and economic life improvement of the family.

There is a pride for Indonesian migrant workers when they can set aside parts of the expenditure for savings, but as the consequences, they have to live as efficient as possible in the destination areas. This economical behavior is reflected through strong willingness tirelessly, frugality and patience in facing any suffers and tribulations. But as workers working in other countries, they often obtain less protection and defenses, especially women workers working in household service sector. This is evident from various kinds of exploitation that 
they have received since the departure to the country where they are working. The red tape departure procedures abroad through the government channels (legal) causes that they choose to use unofficial channels (illegal one). As a result, they must take any consequences of this system, such as exploitation and lack of protection from the government. It is natural that they are going to get any socio-cultural bumps and changes in the destination areas, as well as from their families in their homeland.

International migration of Indonesian migrant workers just obtains serious attention from various parties in the last decades, because there are many problems faced by Indonesian migrant workers, either in the domestic or foreign countries, this starts to take their problem into the surface. The reasons causing this issue as an important one to be study material are because; the first, researchers focusing on the issue of international migration is still relatively new, although after 1975 the Government of Indonesia c.q. Ministry of Man Power, officially conducted "delivery" of Indonesian Migrant Workers - commonly called as TKI - abroad (Mantra and Jeremeas, 1999). Second, some resource sources mention that, the research of international migration in Indonesia is relatively little conducted by Indonesian researchers (Haris, 2001). Third, the fact that labor migration from Tulungagung abroad is no longer dominated by male workers - and this may be a paradox for the migration law by E.G. Ravenstein (1885) that is necessary to be proven. In 1885 , Ravenstein once formulated seven laws of migration, and one of which stated that; "Women tend to migrate in short distances, while men tend to migrate in long distances" (Munir, in Budijanto, 2012). Fourth, more women in the countryside conduct emancipation and later go out from the "wall of tradition" of Patriarchi hegemony giving them limitation in decision-making process in the family. This fact can be seen from the tendency of rural women starting to leave their domestic role by migrating to big cities (Wini, 1999) including working abroad.

Knowing the impact of international migration in the homeland, particularly the influence of migration on social change, it is not as simple as imagined. In the family level, for example, the phenomenon of international migration has resulted in the behavioral pattern changes to children, wives and family relationships. Wives then serving as the head of household, must fulfill their family's daily needs, before there are any remittance deliveries from their husbands. Sometimes there are some wives who face psychological burdens related to their status as single parent whose their husbands leave the country, there are also social pressure and stress because they miss their husbands, and other problems as negative impacts of migrant workers. In certain situations, the inability to meet economic demands and supported by the reality to meet biological needs, these cause a number of irregularities, including infidelity. Further it is stated there are some facts showing that there are some migrant worker couples conduct secret marriages in a customary manner in homeland, as well as in the destination countries. There are then some cases of workers who marry their fellow workers, both from foreign workers and fellow workers. They then settle in the destination country and forget their wives and children living in the homeland.

Indonesian migrant workers in the destination country also face various problems or difficulties, as in the countries such as Saudi Arabia, Malaysia, Singapore and some other countries. Generally, the one facing serious problems is female labors. While, the cases faced by male migrant workers are faced by illegal workers. Wardiyati and Sutami cases are the case of the missing women migrant workers in Singapore, eventually they found dead (Triantoro, 1999). There is also a complaint by Arfiah, who worked in Malaysia, who were mistreated by her employer, locked up for 10 days, and three times her hair was cut off and her salaries were not paid. And there are many more examples of violence cases against migrant workers in the destination country. However, many cases providing negative impacts in both origin and destination countries, still do not discourage other potential migrant workers to work abroad, even in reality, the number of workers who work abroad continues to increase from year to year. It is proven the reason to improve economic welfare of the family as the determination to work abroad, by putting aside all of the risks to face later.

Individual decision to migrate is influenced by complex problems. The current macro flow may easily be predicted through some economic index in various regions. At the end, all of complex individual decisions tend to cause mass migration from the territories having few economic opportunities to areas with greater economic opportunity.

In East Java province, there are some areas as the biggest sender of migrant workers in the province, namely Malang regency, Blitar regency, Tulungagung regency, and Trenggalek regency. These areas in recent years provide the most complete record of data sending the workers abroad than any other regions in East Java. The number of Indonesian migrant workers in these areas can be seen in table 1.1. as follow;

In another aspect, the number of remittances cannot be separated from the homeland areas of the Indonesian migrant workers working such as seen in the table 1.2. as follow:

TABLE. 1 NUMBER OF INDONESIAN MIGRANT WORKERS BASED ON THE COUNTRIES WHERE THE INDONESIAN MIGRANT WORKERS WORK TULUNGAGUNG REGENCY IN 2009

\begin{tabular}{|c|c|c|c|}
\hline No & Countries & Number & $\%$ \\
\hline 1 & S Arabia & 4636 & 22,75 \\
\hline 2 & E Arab & 386 & 1,89 \\
\hline 3 & Malaysia & 1852 & 9,09 \\
\hline 4 & Singapore & 1525 & 7,48 \\
\hline 5 & Korea & 47 & 0,23 \\
\hline 6 & Taiwan & 4739 & 23,25 \\
\hline 7 & Hongkong & 7195 & 35,30 \\
\hline \multicolumn{2}{|c|}{ Total } & 20.380 & 100,00 \\
\hline
\end{tabular}

Source: Man power, trade, transmigration office, Tulungagung regency in 
Table 1 shows that the biggest number of Indonesian migrant workers based on the area where the Indonesian migrant workers work can be divided into three main countries, namely Hongkong, Taiwan, Saudi Arabia, which then Malaysia and Singapore. These big numbers of Indonesian migrant workers according to Man power, trade, transmigration office, Tulungagung regency are caused by the higher salary gained than other countries in southeast Asian regions.

\section{A. Research Problems}

Geographically, Tulungagung regency consists of two groups of areas, namely (1) an area with most area is in the form of limestone mountains with less fertile land condition, which most of its population work in agriculture sector, cultivation in dry land, with an area of cultivation land ownership is average less than 0.2 ha, there is even a family without any cultivation land (landless peasant); (2) an area with most area is in the form of rice fields with fertile soil condition and most of its population work in agriculture sector but the extent of arable land holdings averaging less than 0.2 ha, an area of cultivation land ownership is average less than 0.2 ha, there is even a family without any cultivation land (landless peasant). But from these two regions, there are similarities, namely the difficulty of employment opportunity beyond agriculture sector, there are additional livelihood namely as construction workers and factory workers in Tulungagung. On the other side, there are striking differences between TKI households with non-TKI household showing that most migrant worker family has better socioeconomic level. It can be seen on the permanent and modern style house building, these conditions are rarely found in non-TKI household. This situation indicates that the remittances have been used for various purposes. In addition, demographic characteristics of migrant workers are classified by working age (15-54) years, mostly are in the age of (15-49) years. Therefore, seen from the structure of employment then migrant workers in the region is a potential labor force.

Research on the environmental conditions of migrant workers in the destination country and the remittance delivery to the homeland are divided into four main issues, namely 1) Background of area characteristics in destination countries that are generally associated with great number remittance delivery to the homeland origin; 2) The background of migration status of migrant workers in the destination country workers who are generally associated with great number remittance delivery to their homeland. ; 3). The background characteristics of migrant worker working period in the destination countries are generally associated with great number of remittance delivery to their home land 4) the background characteristics of migrant status in the destination countries are generally associated with great number of remittance delivery to their home land.

\section{METHOD}

Research concerning environmental condition of Indonesian migrant workers in destination countries and the remittance delivery to homeland is designed by quantitative research. This research design includes as explanatory research type using survey technique. The sample is determined purposively namely the districts or village having the biggest number of member of family working as Indonesian migrant workers. The number of sample is 250 families of Indonesian migrant workers taken in simple random sampling technique. The research results are in the form of quantitative data then analyzed descriptively.

\section{FINDING AND DISCUSSION}

According to the research purposes, the research and discussion results to find and reveal the social-economic characteristics (type of occupation, working period, income, status of migrant) in general show the indicators related to the amount of remittance sent by the Indonesian migrant workers to their homeland are as follow:

\section{A. Indonesian migrant workers activity environment in destination countries (X4.1)}

Indonesian migrant workers activity environment in destination countries includes three indicators namely, Indonesian migrant workers activity environment in destination countries, working periods in the destination countries, and status of migration in destination countries.

\section{B. Indonesian migrant workers destination country area}

Basically, any prospective workers want to work in any countries providing high salary, but also providing easy and light requirements. There are many migrant workers working in certain countries because they follow or are invited by relatives and friends who firstly become migrant workers in the areas. As in the results of this research, there are many migrant workers working in Malaysia and Taiwan because of the role of family or friends who are already working in the countries. But, there are also migrant workers working in particular countries as their own initiative or by work offer given by local recruitment agency. To determine the number of migrant workers based on the countries to work, it can be seen in the following table.

TABLE. 2. DISTRIBUTION OF INDONESIAN MIGRANT WORKERACCORDING TO THE COUNTRIES TO WORK IN TULUNGAGUNG REGENCY, IN 2010

\begin{tabular}{|c|c|c|c|}
\hline \multirow{2}{*}{$\begin{array}{c}\text { Destination country } \\
\text { areas }\end{array}$} & \multirow{2}{*}{$\begin{array}{c}\text { Destination } \\
\text { countries }\end{array}$} & \multicolumn{2}{|c|}{ Total } \\
\hline & & $\mathbf{F}$ & $\%$ \\
\hline \multirow[t]{2}{*}{ Middle east $(22,9 \%)$} & Arab Saudi & 55 & 21,8 \\
\hline & Kuwait & 3 & $1,1^{\top}$ \\
\hline \multirow[t]{3}{*}{ Southeast Asian (38\%) } & Malaysia & 67 & 26,6 \\
\hline & Singapore & 22 & 8,8 \\
\hline & Brunai & 7 & 2,6 \\
\hline \multirow[t]{3}{*}{ Far east $(39,1 \%)$} & Taiwan & 50 & 20,0 \\
\hline & Hongkong & 38 & $15, .0$ \\
\hline & Korea & 10 & 4,10 \\
\hline Total & & 250 & 100.00 \\
\hline
\end{tabular}

Source: Man power, trade, transmigration office, Tulungagung regency in

Table 2, it can be seen that most (39.1) respondent families are as migrant workers in the Far East countries, especially Taiwan. Then (38\%) of the respondent family is as the migrant worker family working in Southeast Asian countries, especially Malaysia. Subsequently, there is $(22.9 \%)$ of respondent family 
working as migrant workers in the countries in Middle East region, especially Saudi Arabia. The high percentage of workers is working in the Far East because in the countries, the region has higher salary standard than other regions, it also provides awards on the protection of human labor, especially Korea although in this country, it have applied more stringent rules that all workers working in the country should speak Korean.

While there are many number of respondent family working as the migrant workers in abroad (Malaysia) this is relatively close distance, and low cost. In addition, there are easy requirements to be migrant workers in the country, even illegal workers can also work in the country. Currently, there are Malaysian Government's policies to restrict migrant workers working in the country, so it will be difficult to work in the country, even the illegal ones.

\section{Status of Migration of Indonesian migrant worker in abroad}

The migration process by Indonesian migrant workers in Tulungagung regency is like the migration process in other areas, namely by two path, which are official or legal path and illegal path. The explanation can be seen in the following Table.

TABLE. 3 DISTRIBUTION OF INDONESIAN MIGRANT WORKERS ACCORDING TO THE MIGRATION PATH PROCESS TULUNGAGUNG REGENCY, IN 2010

\begin{tabular}{|l|c|c|}
\hline \multicolumn{1}{|c|}{$\begin{array}{c}\text { Status of Indonesian } \\
\text { Migrant Workers }\end{array}$} & Total & Percentage \\
\hline official (legal) & 59 & 65,6 \\
unofficial (illegal) & 31 & 34,4 \\
\hline Total & 250 & 100 \\
\hline
\end{tabular}

Source: processed primary Data

The table shows that majority of migrant workers working abroad is through official channel, namely there is $65.6 \%$, the remaining by $34.4 \%$ is workers who work abroad using unofficial channel, or more popularly called by illegal TKI. There are many illegal migrants workers working abroad. According to the respondents, the reasons why their family choose the illegal channel are generally because the illegal channel are much cheaper, has easier procedures, and requires no educational requirements. For the illegal migrants going by themselves to Malaysia, the respondents said that they did not complete primary school education.

Workers taking legal channel, according to the respondents, generally have destination countries such as Taiwan, Hong Kong and Korea, because they know that to go there, they must go through official channel. If they use illegal channel, they are still doubtful. The respondents said that by taking official channel to go to Taiwan, Korea, Hong Kong and Arab, prospective workers will know what types of jobs in the country so that the respondents have more confidence that their safety there is assured, even though the cost is higher. More number of workers taking legal channel is not apart from the certainty guarantee of working in the destination country and the rights of workers in the destination country, in addition they wont be afraid of being lied to by the recruitment agency (brokers). These research results in Tulungagung are in line with the results of research conducted by Triantoro (1999) concerning legal and illegal migration to West Malaysia. The results of the study stated that the migration from West Nusa Tenggara who use legal channel was greater in number than the ones using illegal channel.

\section{Working period in destination countries}

Working period in the Destination is the length of labor migrant working. The working period is important because the amount of remittances sent by the migrant workers does not only depend on the standard salary in each country but, it also depends on the working period by the migrant workers abroad. To determine the working period of migrant workers working abroad, it can refer to the Table below.

TABLE. 4 DISTRIBUTION OF INDONESIAN MIGRANT WORKERS ACCORDING TO WORKING PERIOD ABROAD TULUNGAGUNG REGENCY IN 2010

\begin{tabular}{|c|c|c|}
\hline Working period (year) & Frequency & $\%$ \\
\hline$<5$ & 75 & 30,0 \\
$5-<10$ & 94 & 37,7 \\
$10+$ & 81 & 32,2 \\
\hline Total & 250 & 100. \\
\hline \multicolumn{2}{|c|}{ Source: primary Data, processed }
\end{tabular}

Table 4 shows that the largest percentage of workers who work abroad between 5 until 10 years is $37.70 \%$, then the workers who work abroad for 10 years and older is $32.20 \%$. While the migrant workers who work abroad for less than five years is only $30 \%$. According to the conditions, it is necessary to observe the international migration by Indonesian migrant workers (TKI) having miracle changes in their living conditions. In two decades ago, it can be seen that majority of people living in poor condition, in the last 10 years, it has turned into an area at the center of economic activities with diverse condition, having arranged and luxurious neighborhood conditions (99\%) and also permanent, the current transport and communication make the wheel economy has spun in the bustle of economic activities.

\section{E. Remittances}

There are many research results indicating that migrants provide large enough portion of their income for the purpose of remittance. The remittances sent to their families in homeland, according to the survey results, are many through bank and taken already in Rupiah, but some remittances are sent through any friends at the same village who go home in the homeland. The amount of remittances is measured in terms of money received by the family of migrants working abroad. There is irregular delivery time of remittance, there are about six months, one year, but some are only three months sending their remittances. The research results on the amount of remittances can be seen in the following Table. 
TABLE 5. AMOUNT OF REMITTANCE DELIVERY TO THE INDONESIAN MIGRANT WORKER FAMILY TULUNGAGUNG REGENCY, IN 2010

\begin{tabular}{|c|c|c|}
\hline \multirow{2}{*}{$\begin{array}{c}\text { Remittance of TKI } \\
\text { ( Rp juta })\end{array}$} & Frequency & Percent \\
\cline { 2 - 3 } & 53 & 21,20 \\
\hline 55 & 108 & 43,20 \\
\hline $5-<10$ & 89 & 35,60 \\
\hline Total & 250 & 100.00 \\
\hline \multicolumn{2}{|c|}{ Source: primary Data, processed }
\end{tabular}

Tabe1. 5. shows that there is 43.20 percent of migrant workers sending their remittances to their home land ranging between Rp. 5 million until more than USD 10 million. Then, there is $35.60 \%$ of migrant workers sending their remittance ranging more than $\mathrm{Rp} 10$ million. The amount of remittances sent is mainly from the migrant workers working in the Middle East countries (Saudi Arabia) and the Far East countries (Taiwan, Hong Kong and Korea) and there is a small proportion from Malaysia.

There is 21.20 percent of the migrant workers sending their remittances to their homeland less than Rp 5 million, and it is the third largest percentage amount. The remittances sent are mainly from the migrant workers working in Malaysia, most of them are migrant workers have either legal or illegal status. Another thing to know is that there is lower standard salary in Southeast Asian region and moreover, illegal migrant workers has even lower salary standard than the legal workers. In addition, also for migrant working with long enough working period in the country, they have higher salary standard. While, there is to 35.60 percent of migrant workers sending remittances more than $\mathrm{Rp} 10$ million, namely from migrant workers working in the Far East sregion, among of which are from Taiwan, Korea, and Hong Kong. According to the brokers that the author encountered in Ngunut city, currently relatively high salary standards after the United States and Japan, is in Taiwan and Korea. As an example, women Indonesian migrant workers working as domestic servants (PRT) have the standard salary by Rp 6.5 million per month. As for male Indonesian migrant workers in Taiwan working in factory can reach by $\mathrm{Rp}$ 15 million per month, not including overtime payment. This income is far different than women migrant workers working as maids in Malaysia, which only earn Rp 2.5 - 4 million per month. The highest number of remittance received by the families in the homeland is $\mathrm{Rp} 57$ million, and the lowest amount of remittances is USD 1.3 million.

\section{F. Proportion of Remittances on the Total income of the family.}

The amount of remittances that has been described in the previous section is the amount of remittances or goods sent to family of Indonesian migrant worker in the homeland. While, the family total income is the sum of family income in the homeland derived from the remittance delivery by migrant workers working abroad. Therefore, the proportion of remittances on the family income is a large percentage of remittances on the family income. The total family income is the family income per month plus the amount of remittances that have calculated from the average income per month.

Then, it is greatly necessary to assess on the proportion of remittances on the family income. To determine the proportion of remittances on the total income is by dividing the amount of remittances on the total income multiplied by one hundred percent. Further details, it can be assessed in the following Table.

\section{TABLE.6. PROPORTION OF REMITTANCE ON TOTAL FAMILY INCOME IN TULUNGAGUNG REGENCY, IN} 2010

\begin{tabular}{|c|c|c|c|}
\hline No & $\begin{array}{c}\text { Remittance on Total family income } \\
\text { (\%) }\end{array}$ & Frequency & $\%$ \\
\hline 1. & $<40$ & 22 & 8,9 \\
2. & $40-<80$ & 92 & 36,7 \\
3. & $60-<80$ & 86 & 34,4 \\
4. & $80-<100$ & 50 & 20,0 \\
\hline & Total & 250 & 100 \\
\hline \multicolumn{2}{|c|}{ Source: processed primary data }
\end{tabular}

From the Table, it can be seen that there are 92 respondents stating that out of $40 \%-<60 \%$ of total family income, there is $36.7 \%$ from the remittances, and only $8.9 \%$ of respondents stating that their total family income is derived from the remittances namely less than $40 \%$. There is $20.0 \%$ of the respondents stating that more than $80 \%$ of total family income comes from the remittances.

Overall, more than half $(50 \%)$ of respondents stated that their total family income namely, more than $60 \%$ is taken from remittances. Therefore, it appears that the remittance delivery by migrant workers affects on the total family income. These results are confirmed when in the field there are some respondents showing their house improvements, their ability to buy motorcycle, electronics, home investment, all of which are funded by the remittances send by the migrant workers working abroad.

\section{G. Utilization of Remittances in homeland}

In general, there are diverse utilizations of remittances by households in the homeland. Such variations include the fulfillment of family daily life needs, as well as to meet other needs such as children education fees, home renovation, fulfillment on the ownership of household goods, for savings, investment on small businesses and so on.

The use of remittances is grouped into three categories, namely to pay debts, as the consumptive category, and the investment category, such as in Table 6:22.

TABLE .7 DISTRIBUTION OF RESPONDENTS ACCORDING TO THE UTILIZATION OF REMITTANCE TULUNGAGUNG REGENCY IN 2010

\begin{tabular}{|c|c|c|c|}
\hline No & Utilization of Remittance & Frequency & Percentage \\
\hline 1 . & Consumptive & 109 & 43,7 \\
\hline 2. & Investment & 105 & 41,8 \\
\hline 3. & Paying debts & 36 & 14,5 \\
\hline & Total & 250 & 100.00 \\
\hline
\end{tabular}


Table 7 shows the findings of research showing that the biggest remittance utilization priority $(43.7 \%)$ is used for consumptive things, such as to build house or conduct home renovation as well as home furnishings, including electronic goods and automotive (motorcycle). This may be a result that house is a symbol of migrant success, in addition it can also improve their social status. The utilization of remittances for investment (land, jewelry, livestock, fisheries, and savings) in the village is relatively large (41.8\%) although it is lower than consumption. This is because for the family in the homeland, the remittances do not only have economical meaningful, but it is more than having very deep meaning namely in the form of their attitude from family members of migrant workers working abroad in maintaining family relationships. In other words, the delivery of remittances has social impact for the families in the homeland origin. But, the long-term economic impact is already visible through this migration phenomenon. While there is $14.5 \%$ ofuse for paying debts. There is a big percentage of remittance delivery using for houses along with its contents, according to the family of migrant workers, it is because of home renovation or building new homes is a symbol of the success by migrant worker family members.

In general, the use of remittances is allocated for houses, land and home renovation, including motorcycles. But there is also a priority to pay debts, especially for workers who have been working abroad.

\section{IV.CONCLUSIONS AND SUGGESTIONS}

The dysfunctional working environmental condition means that the working environmental condition cannot determine the amount of remittance, although, there are indicators of Indonesian migrant workers in the destination countries, consisting of the country areas as the destination countries by Indonesian migrant workers, status of migration by the Indonesian migrant workers in the destination countries, working period by the Indonesian migrant workers in the destination countries. Out of the three variable indicators, the environment of Indonesian migrant workers giving contribution on the high and low remittance delivered to the Indonesian migrant worker family in the home land is the status of migration by the Indonesian migrant worker in the destination countries.

\section{REFERENCES}

[1] Budijanto, 2012, Analisis Sosio Demografi, Malang: UM Press.

[2] Department of Manpower and Transmigration (Depnakertrans), 2010. Number of Indonesian migrant workers and remittance in Tulungagung regency in 2007 until 2009,

[3] Haris, A, 2001, "Migrasi Internasional, Jaminan Perlindungan dan Tantangan Ekonomi Global", Jurnal Populasi, Volume 12 Nomor 1 Tahun 2001, Research Center of Population, Gadjah Mada University, Yogyakarta.

[4] Goma, Johana Naomi. 1993. Mobilitas Tenga Kerja Flores Timur Ke Sabah Malaysia Dan Pengaruhnya Terhadap Daerah Asal: Studi Kasus Desa Neleren, Kecamatan Adomara Kab. Flores Timur. Yogyakarta, Graduate School, Gadjah Mada University.

[5] Mantra, I.B. and Jeremeas 1999, "Mobilitas Penduduk dan Dampaknya terhadap Daerah yang Ditinggalkan: Studi Kasus Kabupaten Sukoharjo, Madiun, Ciamis dan Asahan". (Final Report), in collaboration between
Office of Ministry of Population and Environment and Yogyakarta Center of Population Research Gadjah Mada University.

[6] Salladien, 1999. Refleksi Pemahaman Mobilitas Penduduk sebagai Upaya Peningkatan Sosial Ekonomi, Brawijaya University Malang. pages 1-21.

[7] Setiadi, 2004. Masalah Reintegrasi Sosial dan Ekonomi Migran Kembali. Jurnal Populasi Volume 10 Nomor 2. Research Center of Population, Gadjah Mada University, Yogyakarta.

[8] Triantoro, 1999, "Migrasi Legal dan Ilegal ke Malaysia Barat kasus Migrasi Internasional di Pulau Lombok, NTB", Jurnal Populasi Volume10 Nomor 2 Tahun 1999, Research Center of Population, Gadjah Mada University, Yogyakarta.

[9] Wini. T, 1999, "Dampak Migrasi Tenaga kerja ke Malaysia", Jurnal Populasi Volume10 Nomor 2 Tahun 1999, Research Center of Population, Gadjah Mada University, Yogyakarta. 